\title{
PERAN WANITA PERSATUAN PEMBANGUNAN DALAM REKRUTMEN PEREMPUAN DI PARTAI PERSATUAN PEMBANGUNAN
}

\author{
Evi Yunita Kurniaty ${ }^{1}$, Bimby Hidayat ${ }^{2}$, Syahrial Efendy ${ }^{3}$, Rudi Salam Sinaga ${ }^{4}$. \\ 1,2,4 Jl. Kolam No 1 Medan Estate-Medan. Dosen Ilmu Pemerintahan Universitas Medan Area \\ ${ }^{3}$ Jl. Sultan Serdang-Tanjung Morawa. Deli Serdang \\ email: evithalib@gmail.com
}

Diterima: 7 November 2016/ Disetujui: 19 November 2016

\begin{abstract}
Abstrak
Studi ini bertujuan unutk mengkaji peran wanita persatuan pembangunan (WPP) dalam melakukan rekrutmen politik kaum perempuan di Partai Persatuan Pembangunan (PPP). Kajian ini dibatasi pada area Pemilu tahun 2009. Metode kualitatif dengan jenis studi kasus digunakan untuk menjawab pertanyaan penelitian ini. Hasil penelitian mendapatkan bahwa peran WPP amat bergantung pada penempatan peran yang ditetapkan oleh partai (PPP) dalam studi ini terlihat upaya WPP untuk meningkatkan jumlah partisipasi perempuan masuk ke arena politik seperti pengurus partai dan calon legislatif.

Kata Kunci : Rekrutmen, Perempuan, PPP, WPP.
\end{abstract}

\begin{abstract}
This study aims to examine the role of women unity development (WPP) in performing political recruitment of women in the United Development Party (PPP). This review is limited to the 2009 Election area. Qualitative methods with case study types are used to answer this research question. The result of the study found that the role of WPP is very dependent on the placement of roles defined by the party (PPP) in this study seen WPP efforts to increase the number of women's participation into the political arena such as party leaders and legislative candidates.
\end{abstract} Keywords: Recruitment, Women, PPP, WPP. 


\section{PENDAHULUAN}

Ann Oakley mengartikan bahwa gender adalah sebuah konstruksi sosial atau atribut yang dikenakan pada manusia yang dibangun oleh kebudayaan manusia. Dan Mansour Fakih mengungkapkan gender merupakan suatu sifat yang melekat pada laki-laki maupun perempuan yang dikonstruksikan secara sosial maupun kultural, akan tetapi sesungguhnya perbedaan sifat antara laki-laki maupun perempuan dapat berubah ataupun dipertukarkan. Oleh sebab itu salah besar apabila mengartikan gender sebagai kodrat Tuhan seperti halnya sex. Bukan tidak ada laki-laki yang lembut dan juga perempuan yang kuat, karena hal tersebut dapat bertukar sesuai dengan kasus maupun tempatnya. Akan tetapi yang sering menjadi permasalahan yang mendasar adalah mengartikan sex dan gender sebagai suatu hal yang sama. Bahwa perempuan dikodratkan sebagai makhluk lemah yang perlu perlindungan dari laki-laki, sehingga laki-laki berperan sebagai seseorang yang kuat sebagai pelindung perempuan, sehingga berada di 'atas' perempuan. Pembedaan antara laki-laki dan perempuan inilah yang secara tidak sadar menempatkan perempuan pada kelas dua, yaitu berada dibawah lakilaki. Disisi lain penafsiran agama yang hanya sepotong-potong yang membedakan antara posisi laki-laki dan perempuan, yang pada sesungguhnya Tuhan tidak pernah membedakan umatnya melainkan dari tingkat ketakwaannya. Pemahaman yang sepotong-potong inilah yang juga membuat perempuan semakin tersubordinasi.

Begitu juga di dalam dunia politik, dunia politik yang dianggap dunia yang kotor, diartikan sebagai dunianya laki-laki. Laki-laki dianggap cukup kuat untuk berada didunia politik yang kotor, sedangkan perempuan tidak. Ini adalah salah satu hal yang mendorong sedikitnya perempuan yang berada didunia politik dan ditambah lagi dengan pemahaman gender yang salah tersebut. Ketika berbicara mengenai dunia politik, kita juga berbicara mengenai pembuatan dan pengesahan kebijakan. Apa yang akan terjadi apabila tidak ada ataupun sedikit sekali perempuan yang ikut dalam pembuatan maupun pengesahan kebijakan? Dapat dibayangkan bahwa kebijakankebijakan yang dibuat adalah kebijakankebijakan yang paternalistik yang tidak begitu mempertimbangkan perempuan sebagai pelaksana kebijakan tersebut. Sehingga sejak dahulu sudah banyak gerakan-gerakan perempuan yang menyuarakan pembedaan yang dialami oleh perempuan, sehingga diperlukannya keterwakilan perempuan dalam pembuatan maupun pengesahan kebijakan. Di Indonesia gerakan-gerakan perempuan pertama kali membuat kongres perempuan pertama pada 22 desember 1928 di Yogyakata. Yang menjadi pokok pembahasan besar adalah pendidikan modern bagi perempuan muda dan juga tentang pernikahan yang memarginalkan kaum perempuan. Dan pada kongres ini menghasilkan pendirian Perikatan Perempuan Indonesia (PPI), yang berniat mengembangkan posisi sosial kaum perempuan dan kehidupan keluarga secara menyeluruh. Pada kongres kedua, poligami dan pelacuran menjadi permasalahan yang dibahas. Dan pada kongres ketiga yang menjadi pokok pmbahasan adalah hak memilih. Kongres-kongres ini menjadi tombak bagi pergerakan perempuan di indonesia. Terlihat jelas bahwa masalahmasalah perempuan khususnya di indonesia sudah menjadi pembahasan sejak zaman kolonial. Perempuan terus menuntut haknya. Misalnya melalui gerakan/organisasi perempuan. Dalam suatu gerakan yang kuat dan besar, merupakan salah satu sarana untuk melakukan perubahan. 
Dari tahun ketahun gerakan perempuan terus berkembang akan tetapi secara tidak sadar penulis beranggapan bahwa hal-hal yang menjadi persoalan belum berubah secara signifikan. Seperti halnya hak memilih, memang pada saat ini perempuan sudah memiliki hak untuk memilih, akan tetapi tidak begitu dengan hak untuk dipilih. Pemahaman mengenai gender yang salah membuat kaum perempuan bukan menjadi seseorang yang diprioritaskan untuk dapat dipilih sebagai pembuatan dan pengesah kebijakan. Anggapan bahwa kaum perempuan hanya berada pada ruang domestik atau sudah bisa berada dalam ruang publik akan tetapi tetap menjadi penanggung jawab utama dalam ruang domestik, membuat kaum perempuan sangat sulit untuk berada dalam ruang publik. Sedangkan dalam melakukan perubahan-perubahan tersebut, perempuan harus berada dalam ruang publik.

Ketika berbicara mengenai pembuatan maupun pengesahan kebijakan, kita akan membahas mengenai legislative yang didalamnya terdapat partai-partai politik. Partai politik merupakan wadah untuk menampung aspirasi rakyat. Melalui partai politik kita dapat turut serta dalam dunia politik. Suatu partai politik memiliki suatu struktur organisasi dan juga organisasi atau sayap-sayap untuk mendukung keberadaan partai politik tersebut. Penulis sangat tertarik untuk melihat sayap perempuan didalam partai. Seperti yang sudah dijelaskan diatas bahwa ada pemahaman mengenai agama yang sepotong-potong yang menjadi akibat perempuan menjadi subordinasi. Oleh sebab itu penulis sangat tertarik untuk meneliti mengenai partai politik yang berazaskan agama, dalam thesis ini penulis mengambil studi kasus Wanita Persatuan Pembangunan (WPP) sebagai satu-satunya organisasi perempuan yang berada pada Partai Persatuan Pembangunan (PPP).

Betapa pentingnya agar perempuan dapat duduk didalam suatu lembaga legislative. Data perempuan yang duduk di parlemen di dunia rata-rata hanya $14 \%$ dari total anggota parlemen (data UNDP). Di Indonesia pada periode 2009-2014 hanya mencapai sekitar 18\%. Padahal di Indonesia pemilih perempuan dalam Pemilu lebih tinggi daripada laki-laki, jumlah penduduk perempuan juga hampir sama dengan lakilaki. Sebuah Negara yang demokratis seperti Indonesia seharusnya memberikan kesempatan yang sama terhadap laki-laki dan perempuan. Perempuan juga memiliki hak untuk dipilih, untuk mengambil keputusan dan lain sebagainya seperti kesempatan yang diberikan kepada laki-laki. Undang - Undang nomor 10 tahun 2008 tentang Pemilu anggota DPR, DPD dan DPRD yang menetapkan kuota setidaknya $30 \%$ untuk perempuan. Diikuti dengan menempatkan caleg perempuan secara zipper yaitu pada setiap 3 orang caleg terdapat 1 orang caleg perempuan. Tidak banyak partai politik yang dapat memenuhi kuota 30\% ini, karena sulitnya mencari kader-kader perempuan yang berkualitas dan mampu bersaing.

Kondisi perempuan dalam bidang politik, yang dapat tercermin dalam keterwakilan perempuan di DPR. Pada Pemilu 1997, perempuan hanya terwakili 9,7\% di DPR. Pemilu 1999, menurun menjadi 8,4\%. Pemilu 2004 naik menjadi 11,5\%. Dan pada Pemilu 2009, paling tinggi dalam sejarah politik di Indonesia sebanyak 18\%. Akan tetapi ini masih jauh dari kuota perempuan yang seharusnya minimal $30 \%$ perempuan duduk sebagai anggota DPR.

Partai politik juga yang menentukan pelung untuk para calon legislatif perempuan untuk dapat ikut serta dalam Pemilu. Ketika kita berbicara mengenai 
Pemilu dan rekrutmen calon legislatif, kita tidak dapat melepaskan diri dari penentuan daftar calon sementara dan daftar calon tetap. Setiap partai politik yang mengikuti Pemilu memiliki badan tersendiri didalam partai politik tersebut untuk menentukan daftar calon sementara dan daftar calon tetap tersebut. Didalam Partai Persatuan Pembangunan badan ini disebut dengan Latjnah Pemenangan Pemilu (LP2). Selain menentukan daftar calon sementara dan daftar calon tetap, LP2 juga membantu dalam strategi pemenangan Pemilu dan segala sesuatu yang berkaitan dengan Pemilu tersebut.

Masalah yang diangkat sebagai isu pokok permasalahan cenderung berada dalam ruang lingkup yang luas dan mendalam. Dari latar belakang diatas, penulis mencoba membuat suatu perumusan masalah sebagai berikut: Bagaimanakah peran WPP dalam menyiapkan kader-kader perempuan PPP? Sejauh mana WPP ikut serta dalam pengambilan kebijakan, terutama yang menyuarakan tentang kaum perempuan? Dan bagaimanakah implentasi rekomendasi Wanita Persatuan Pembangunan dalam keterwakilan perempuan PPP untuk dapat duduk di legislatif.

\section{KAJIAN TEORI}

\section{Perspektif gender}

Pengertian perspektif, berasal dari bahasa inggris perspective, yang diartikan sebagai pandangan, wawasan, maupun cara pandang. Dengan demikian perspektif gender merupakan sebuah cara pandang atau wawasan dalam melihat persoalan atau suatu masalah berdasarkan atas pemahaman akan konsep gender. Untuk mengetahui bagaimana pandangan/wawasan secara peka gender ini maka sebelumnya perlu dikenali terlebih dahulu apa itu gender, bagaimana konsep itu muncul dan persoalan-persoalan apakah yang berkaitan dengan konsep gender ini. Seseorang atau suatu kelompok memiliki pandangan/wawasan peka gender ini akan terefleksi dalam sikap-sikap maupun tingkah laku (perbuatannya) dalam berbagai bidang kehidupan termasuk didalamnya kehidupan politiknya. Sehingga kita bisa melihat pandangan peka gender (perspektif gender) sesorang atau suatu kelompok berdasarkan pada pemikiran, perkataan, sikap dan tingkah laku orang atau kelompok tersebut yang memperhatikan kesetaraan antara perempuan dan laki-laki. Dalam melihat perspektif gender partai politik, kita bisa mengukurnya memlalui bagaimana program-program yang diajukan oleh partai politik yang bersangkutan, apakah dalam program tersebut cukup memberikan tempat bagi kesetaraan gender. Yang artinya seberapa jauh program yang dibuat oleh partai telah memperhatikan aspek kesetaraan dan memberikan peluang yang sama antara laki-laki maupun perempuan untuk berpartisipasi dalam partai politik. Program dimaksud juga harus memberikan perhatian atas kesenjangan gender yang ada dalam masyarakat selama ini baik yang ditimbulkan oleh factor budaya maupun sosialisasi. Perspektif gender elit politik juga dapat diukur melalui pernyataan-pernyataan sikap maupun prilaku elit politiknya. Bagaimana elit partai politik yang bersangkutan peka dalam menanggapi persoalan-persoalan perempuan dan ketidak adilan yang dialami, bagaimana elit tersebut memperjuangkan kepentingan perempuan dalam setiap pembahasan produk perundang-undangan, bagaimana elit tersebut menanggapi persoalan, isu kesetaraan dan lain sebaginya.

Sedangkan partai politik menurut Sigmund Neuman adalah bagaimana kelompok dalam kelompok yang terorganisir memperebutkan kekuasaan harus bersaing dengan kelompok lain sejenis yamg berbeda 
pandangan. Dengan lengkap Neuman mengungkapkan definisnya sebagai berikut:

A political party is the articulate of society's active political agenis, those who care concerned with the control of government power and who compete for popular support with group or groups holding divergent views.

Partai politik dan lembaga legislatif merupakan dua aktor utama masyarakat politik, yang memperoleh mandat dari masyarakat sipil, berperan mengorganisir kekuasaan dan meraih kontrol atas negara untuk kepentingan masyarakat. Peran partai politik itu diletakkan dalam arena pemilihan umum, yang di dalamnya terjadi kompetisi antarpartai dan partisipasi politik masyarakat sipil untuk memberikan mandat pada partai atau kandidat pejabat politik yang dipercayainya. Secara universal, peran utama partai politik adalah memegang kekuasaan negara, apabila berhasil memperoleh suara mayoritas dalam pemilu. Fungsi lain partai politik adalah menyiapkan kader-kader pemimpin, pendidikan politik bagi rakyat, sarana partisipasi dan komunikasi politik.

Alan Ware mendefinisikan partai politik ke dalam tiga kategori. Pertama, partai politik sebagai institusi yang membawa rakyat secara bersama-sama dalam mencapai kekuasaan di dalam negara. Kedua, partai politik sebagai lembaga yang mencari perwakilan kepentingan di dalam sebuah masyarakat. Ketiga, partai politik adalah sekelompok orang atau masyarakat yang mempunyai kesamaan ideologi, nilai dan perilaku.

Lebih lanjut Alan Ware mengemukakan tiga insentif, yang dapat diberikan oleh partai politik (terutama partai kader) untuk menarik massa ke dalam partai politik. Pertama, insentif materiel seperti memberikan uang untuk menyelenggarakan kampanye, memberikan kesempatan kerja di dalam pemerintah, pemberian proyek-proyek pembangunan tertentu dan lain-lain. Insentif ini jelas bermakna keuntungan yang bersifat kebendaan bagi individu tertentu. Kedua, insentif solider, adalah insentif yang tidak tampak dan lebih diperuntukkan buat kelompok. Di sini keterlibatan di dalam partai antara lain terdorong karena ajakan teman dan ikut dalam kegiatan-kegiatannya. Mereka yang aktif dalam partai akan memperoleh keuntungan politis, tetapi bisa juga memberikan manfaat sosial. Ketiga, insentif tujuan. Yang terkait dengan tujuan terutama adalah ideologi atau programprogram kebijakan umum partai. Kegiatan partai lebih ditujukan pada sosialisasi. Namun di dalam aktivitas pencapaian tujuan dapat pula menimbulkan ketegangan internal partai.

Dalam upaya membangun kesinambungan kehidupan suatu partai politik, maka partai politik perlu melakukan rekrutmen politik untuk mengisi kepengurusan serta keanggotaan partai, termasuk untuk menempatkan wakilwakilnya dalam lembaga legislatif (parlemen). Selain itu hal ini juga dimaksudkan untuk memperoleh kaderkader partai yang handal untuk memenangan pertarungan merebut kekuasaan melalui pemilu. Kader partai atau orang dari luar partai yang diseleksi oleh partai untuk diorbitkan menjadi politisi di lembaga perwakilan selanjutnya berkompetisi dalam Pemilu. Sistem pemerintahan atau demokrasi perwakilan tidak bisa dipisahkan dari Pemilu. Pemilu sebagai salah satu instrumen demokrasi modern, merupakan ajang kompetisi kaum elit.

Namun demikian, menurut Rush dan Althoff, di kebanyakan negara berkembang, proses perekrutan sering dilakukan melalui 
saluran informal berdasarkan kelompokkelompok tradisional, kesukuan, etnis atau kedaerahan. Metode perekrutan tradisional ini walaupun melalui lembaga-lembaga modern seperti partai politik namun masih mencakup relasi-relasi informal, kekeluargaan, dan relasi-relasi etnis yang menonjol dan berkuasa Rekrutmen politik adalah penyeleksian individu-individu yang berbakat dan memenuhi prasyarat untuk menduduki jabatan politik. Lebih khusus lagi, rekrutmen caleg adalah penyeleksian individu-inidividu yang berbakat dan telah memenuhi parasyarat untuk menjadi anggota legislatif, baik dalam proses penjaringan maupun penyaringan calon.

Menjadi fenomena yang umum bahwa lembaga perwakilan yang ada, "kurang mewakili" semua kelompok dalam masyarakat terutama kelompok minoritas dan terpinggirkan. Tuntutan bahwa kelompok minoritas tidak sepenuhnya terwakili dalam badan legislatif, dibaca oleh Will Kymlicka, "tampak mengandaikan bahwa rakyat hanya dapat 'diwakili' secara penuh oleh seseorang dari jenis kelamin, kelas, pekerjaan, etnisitas dan bahasa yang sama, dan lainlain" Menyitir pendapat Birch dan Pitkin, Will Kymlicka menyebutkan bahwa perwakilan seperti yang disebutkan diatas disebut "perwakilan cermin/mirror representation." Suatu kelompok warga dikatakan diwakili dalam badan legislatif apabila satu atau lebih dari anggota Dewan merupakan jenis orang yang sama dengan warga.

Kymlicka menyebutkan alasannya bahwa orang harus mempunyai pengalaman atau karakteristik tertentu yang sama agar dapat benar-benar memahami kebutuhan dan kepentingan masing-masing. Atas pandangan itu, seorang laki-laki kulit putih tidak tahu apa yang menjadi kepentingan seorang perempuan atau seorang laki-laki kulit hitam. Seorang laki-laki walaupun menumpahkan banyak perhatian atau rasa simpati, dengan hati-hati dan jujur, kesemuanya itu tidak bisa malampaui batasbatas pengalaman. Hal tersebut dikuatlan oleh Christine Boyle yang menyatakan bahwa: "karena kepentingan laki-laki berbeda dengan kepentingan perempuan dalam hal pendapatan, diskriminasi, hak-hak hukum, dan pengasuhan anak, bisa disimpulkan bahwa tidak mungkin bagi lakilaki mewakili perempuan. Alasannya bukannya harus bahwa laki-laki tidak memahami kepentingan perempuan, melainkan bahwa pada titik tertentu para anggota dari satu kelompok merasa bahwa seseorang dari kelompok lain mempunyai konflik kepentingan sehingga perwakilan tidaklah mungkin, atau setidaknya sulit".

Pada umumnya proses rekrutmen poltik dapat dilakukan dengan beberapa cara atau sifat. Ada dua cara untuk melakukan rekrutmen politik yaitu secara terbuka dan secara tertutup. Rekrutmen politik terbuka mengandung makna bahwa semua warga negara yang memenuhi syarat-syarat yang ditentukan serta mempunyai bakat, tanpa kecuali mempunyai kesempatan yang sama untuk menduduki jabatan politik maupun jabatan pemerintahan. Sebaliknya, rekrutmen politik tertutup hanya memberikan kesempatan kepada orangorang tertentu seperti kawan-kawan akrab penguasa, atau individu-inidividu yang mempunyai persamaan agama, daerah, etnis bahkan keluarga dari pihak penguasa.

Secara teoritis, rekrutmen dengan sistem terbuka berarti menerapkan merit system, yaitu suatu seleksi menurut kualifikasi teknis, rasional dan impersonal. Sedangkan dalam hal rekrutmen caleg, harus mencerminkan perwakilan yang sebenarnya dari masyarakat. Menurut Imawan, seleksi anggota legislatif harus memenuhi syaratsyarat kapabilitas, popularitas dan akseptabilitas. Ketiga syarat ini harus 
dipadukan. Artinya sesorang kandidat harus benar-benar memiliki kemampuan, populer di tengah-tengah masyarakat, diterima oleh masyarakat serta terpilih melalui prosedur perwakilan, bukan hanya sekadar ditunjuk.

Dalam sistem rekrutmen terbuka ini, setiap warga bebas berkompetisi untuk menjadi caleg tanpa tekanan dan batasanbatasan tertentu oleh kekuatan eksternal. Suasana kompetisi untuk mengisi jabatan biasanya sangat tinggi, sehingga orangorang yang benar-benar sudah teruji saja yang akan berhasil keluar sebagai pemenang. Ujian tersebut menurut Afan Gaffar biasanya menyangkut visinya tentang keadaan masyarakat, atau yang dikenal sebagai platform politiknya serta nilai moral yang melekat dalam dirinya termasuk integritasnya.

Partai politik merupakan wadah untuk menciptakan kesetaraan dan keadilan gender, dalam berbagai aspek kehidupan bernegara dan berbangsa. Partai politik juga telah diberi kepercayaan dalam affirmative action, yaitu menguatnya pemberdayaan politik perempuan dengan mendapat perwakilan sebesar 30\%. Hal tersebut merupakan keberhasilan dari perjuangan para feminis yang sudah berabad-abad dalam bidang politik. Ada beberapa argumentasi yang dimunculkan oleh para feminis ketika memperjuangkan affirmative action ini. Pertama, diperlukan intervensi struktural sebagai tindakan darurat untuk mengatasi ketimpangan gender dalam waktu yang cepat. Kedua, keterwakilan perempuan dibidang politik masih sangat rendah sehingga dibutuhkan kuota bagi perempuan. Ketiga, nilai-nilai hidup perempuan mempunyai cirri khas tertentu, misalnya kepedulian pada isu kesejahteraan keluarga, pendidikan, kesehatan, anti kekerasan dan lain-lain. Selain itu dalam banyak hal kaum perempuan dapat melakukan tindakan kooperatif, consensus, dan bertoleransi dibandinkan dengan laki-laki. Sehingga bila dibawa kedalam kehidupan politik, etika perempuan itu akan berdampak positif yaitu memiliki tingkat kepedulian yang tinggi yang bukan hanya menonjolkan keadilan.

Lahirnya affirmative action ini menimbulkan pro dan kontra. Mereka yang pro terhadap kebijakan tersebut menganggap angin segar, tapi masih memuncukan kekhawatiran lebih lanjut. Namun setidaknya kebijakan affirmative action ini merupakan peluang bagi kaum perempuan untuk dapat berpartisipasi di bidang politik. Sebagai wadah untuk berpartisipasi dalam bidang politik, partai politik merupakan tempat yang tepat, karena didalam partai politik kaum perempuan mendapat pendidikan politik dan etika politik. Namun dari kenyataan yang ada, partai politik tidak sepenuhna dapat merekrut kaum perempuan karena berbagai pertimbangan yang sudah klasik, yakni perempuan belum cocok masuk kedalam sector ini. Hal yang harus dipertimbangkan oleh kaum politikus adalah bahwa menerima kaum perempuan, harus dengan pertimbangan nilai-nilai humanism dan liberalisasi, bukan aktifitas politik semata-mata. Nilai profetis yang dimaksud adalah humanism, liberalisasi dan transendensi.

Meskipun banyak argumen yang menerangkan pentingnya keterlibatan dan keterwakilan perempuan dalam politik, tetapi kondisi empiris juga menunjukkan banyaknya faktor yang menghambat partisipasi politik perempuan. Center for Asia-Pasific Women in Politics mencatat adanya dua faktor utama, yaitu: (1) Pengaruh dari masih mengakarnya peran dan pembagian gender antara laki-laki dan perempuan yang tradisional yang membatasi atau menghambat partisipasi perempuan di bidang kepemimpinan dan pembuatan kebijakan atau keputusan; dan (2) Kendalakendala kelembagaan (institusional) yang 
masih kuat atas akses perempuan terhadap kekuasaan yang tersebar di berbagai kelembagaan sosial-politik, antara lain tipe sistem pemilihan umum (pemilu).

Salah satu bentuk affirmative action adalah pemberian kuota dalam jumlah tertentu bagi perempuan. Ide inti di balik sistem kuota adalah merekrut perempuan untuk masuk dalam posisi politik dan memastikan bahwa perempuan tidak sekedar merupakan sedikit "tanda" dalam kehidupan politik. Kuota bagi perempuan merupakan suatu jumlah tertentu atau persentase dari anggota suatu badan, apakah itu suatu daftar kandidat (calon anggota legislatif/caleg), majelis parlemen, suatu komite, atau suatu pemerintahan. Kebijakan ini bertujuan untuk memastikan agar perempuan, paling tidak, merupakan satu "minoritas kritis" (critical minority) yang terdiri dari $30 \%$ atau $40 \%$. Satu hal yang penting adalah bahwa kuota ini hanya diterapkan sebagai tindakan temporer. Apabila hambatan struktural terhadap masuknya perempuan dalam politik telah dapat disingkirkan, maka kuota tidak perlu diterapkan lagi. Hal ini tidak terlepas dari dasar pertimbangan penerapan kuota itu sendiri, yaitu perempuan tertinggal jauh "start" nya ketika memasuki dunia politik dibanding dengan laki-laki. Oleh karena itu kuota tidak diperlukan lagi ketika keduanya sudah berada pada garis start yang sama.

Sebagian besar kuota menggunakan angka 30\%, karena angka 30\% diyakini sebagai "angka kritis" (critical number) yang harus dicapai untuk memungkinkan sebuah perubahan. Angka 30\% menunjukkan massa kritis (critical mass) yang akan memberikan dampak pada kualitas keputusan yang diambil dalam lembaga-lembaga publik. Jumlah 30\% ditetapkan untuk menghindari dominasi dari salah satu jenis kelamin dalam lembagalembaga politik yang merumuskan kebijakan publik. Angka 30\% sebagai critical minority ini sesuai dengan Laporan Perkembangan PBB Tahun 1995 yang menganalisa gender dan pembangunan di 174 negara.

\section{METODE PENELITIAN}

Dalam melaksanakan penelitian ini peneliti memakai metode pendekatan kualitatif, yaitu suatu pendekatan yang dilakukan untuk memahami makna maupun proses dari obyek penelitian, karena itu untuk memperoleh data yang akurat peneliti akan langsung terjun ke lapangan dan memposisikan dirinya sebagai instrumen penelitian yang menjadi salah satu ciri penelitian kualitatif. Untuk mengetahui secara mendalam gender equality (kesetaraan gender) pada Partai Persatuan Pembangunan, peneliti menggunakan pendekatan penelitian kualitatif deskriptif. Dimana deskriptif di sini berusaha mendeskripsikan dan menginterpretasikan tentang kondisi yang terjadi di lapangan. Penelitian deskriptif sangat relevan digunakan dalam ilmu perilaku karena berbagai bentuk tingkah laku yang menjadi pusat perhatian peneliti dapat disengaja diatur dalam latar realitas. Penelitian deskriptif juga biasa disebut penelitian eksperimen, yang berkenaan dengan berbagai variabel, menguji hipotesis dan mengembangkan generalisasi yang memiliki validalitas universal.

\section{HASIL DAN PEMBAHASAN Perempuan dan Partai Persatuan Pembangunan}

Perjalanan mengenai keterwakilan perempuan di Partai Persatuan Pembangunan dimulai ketika muktamar V tahun 2003, steering committee dibentuk untuk persiapan muktamar tersebut. Kemudian steering committee menunjuk 7 orang untuk menjadi sebuah team dalam mempersiapkan amandemen anggaran dasar 
dan anggaran rumah tangga (ADART) PPP yang akan dibahas ketika muktamar. 7 orang dalam team tersebut terdiri dari 5 orang lakilaki dan 2 orang perempuan (lena marlena dan khotidjah). Pada muktamar $\mathrm{V}$ tahun 2003 inilah terjadi perombakan besarbesaran pada ADART PPP; yang salah satunya membahas tentang keberadaan perempuan. Pada usulan ADART ini dibahas tentang keterwakilan perempuan pada PPP, yang ketika periode Aisyah Aminy, hanya ada Aisyah Amini sendiri dari 45 orang pengurus lainnya yang laki-laki. Pada periode berikutnya menjadi 2 orang perempuan dan setelah itu hanya ada 3 orang perempuan dari pengurus lainnya. Terlihat jelas bahwa keterwakilan perempuan belum berjalan adil di PPP ketika itu.

Kembali pada pembahasan team yang terdiri dari 7 orang untuk persiapan muktamar pada tahun 2003. Usulan awal adalah masuknya keterwakilan perempuan pada bab kepemimpinan. Usulan ini ditentang oleh para anggota team laki-laki yang lain, melalui perdebatan yang panjang yang selalu diakhiri dengan datelock, usulan lain muncul agar pembahasan keterwakilan perempuan ini masuk pada bab lain-lain. Isi dari pembahasan ini adalah diseluruh jenjang kepemimpinan Partai Persatuan Pembangunan, harus memperhatikan keterwakilan perempuan. Akan tetapi ditambahkan oleh para anggota team lakilaki yang lain dengan kata 'sesuai dengan kemampuannya'. Hal ini disebabkan dengan keraguan para anggota team laki-laki, dengan kemampuan perempuan dalam menduduki jabatan-jabatan tersebut. Karena keadaan yang selalu datelock ini, akhirnya usulan tersebut diputuskan dengan isi 'setiap tingkatan kepemimpinan Partai Persatuan Pembangunan harus memperhatikan kesetaraan dan keadilan gender berdasarkan kualitas sumber daya manusia', dan masuk pada bab lain-lain.

Ketika muktamar tahun 2007, Lena Marlena terpilih menjadi sekretaris steering committee untuk muktamar. Akan tetapi tidak jarang beliau memimpin rapat-rapat steering untuk menggantikan ketua steering. Yang menjadi puncaknya adalah ketika beliau memimpin muktamar. Keinginan yang sudah lama dalam memperjuangkan keterwakilan perempuan akhirnya di usulkan kembali pada muktamar pada tahun 2007 ini. Mengusulkan kembali keterwakilan perempuan pada bab kepemimpinan, dan menyebutkan jumlah nominal bahwa didalam pengurus harian Dewan Pimpinan Pusat pada setiap 37 orang laki-laki, setidaknya harus ada 7 orang perempuan. kemudian pada wilayah harus ada 5 orang perempuan dan pada cabang harus ada 4 atau 3 orang perempuan. Mengapa tidak $30 \%$ ? Karena memang susahnya mendapatkan perempuan yang siap dalam melakukan penekanan, ikut serta mempengaruhi dan ikut dalam pengambilan keputusan. Dan kemudian keputusan ini disahkan dalam muktamar pada tahun 2007.

Perkembangan kursi perempuan dalam DPR di Partai Persatuan Pembangunan pada periode 2004-2009 dan 2009-2014. Pada periode 2004-2009 ada 3 orang perempuan PPP yang duduk di DPR, akan tetapi ketika Suryadharma Ali mengundurkan diri untuk menjadi menteri, bertambah menjadi 4 orang perempuan dari 37 kursi PPP yang ada di DPR ketika itu. Dan pada periode 2009-2014 dalam jumlah bertambah menjadi 5 orang perempuan. Dengan yang memiliki latar belakang aktivis 2 dari 5 orang perempuan yang duduk pada kursi DPR PPP periode ini. 


\section{Wanita Persatuan Pembangunan Pada Pemilu 2009}

Sebagai organisasi otonom yang sudah sejak lama berdiri Wanita Persatuan Pembangunan banyak berperan dalam pengusahaan peningkatan kualitas perempuan pada Partai Persatuan Pembangunan. Bersinergi dengan AD/ART Partai Persatuan Pembangunan bahwa pada bab kepemimpinan yang mengemukakan didalam pengurus harian Dewan Pimpinan Pusat pada setiap 37 orang laki-laki, setidaknya harus ada 7 orang perempuan. kemudian pada wilayah harus ada 5 orang perempuan dan pada cabang harus ada 4 atau 3 orang perempuan, membuat WPP semakin giat dalam melaksanakan programprogramnya. Dalam rekomendasi Wanita Persatuan Pembangunan dalam Munas I WPP, rekomendasi WPP terhadap WPP diantaranya adalah: tidak mengeluarkan SK kepengurusan untuk DPW dan DPC Partai Persatuan Pembangunan yang tidak mencantumkan unsur perempuan minimal $30 \%$, memasukkan pengurus harian WPP disemua tingkatan sebagai pengurus harian PPP disemua tingkatan. Hal ini akan membantu meningkatkan kesadaran kader perempuan untuk ikut berpartisipasi didunia politik dan memberikan tempat bagi para kader-kader perempuan PPP agar dapat terjun didunia politik. Dalam hal rekrutmen calon legislative seperti yang terdapat dalam rekomendasi WPP terhadap DPP PPP, setiap calon perempuan harus mendapatkan rekomendasi dari WPP dalam setiap tingkatan, dengan memperhitungkan keaktifan, kapabilitas dan lamanya berjuang dalam PPP. Sehingga WPP sangat berperan dalam rekrutmen perempuan PPP untuk duduk sebagai caleg.

Dalam hal persiapan atau pelatihan bagi para caleg maupun kader WPP, seperti yang dapat kita lihat di programprogramnya, WPP mengadakan pelatihan- pelatihan untuk kader perempuan PPP sebagai modal dasar untuk terjun didalam dunia politik. Begitu juga pada persiapan Pemilu 2009, diantaranya WPP mengadakan pelatihan Trainning of Trainers (TOT); pelatihan kepemimpinan yang diadakan bagi para trainers. WPP dimana pada pelatihan ini, para trainers yang dilatih akan melakukan pelatihan kembali untuk para kader WPP sampai ketingkat ranting. Pelatihan kewirausahaan, bukan hanya didunia politik, bagi WPP perempuan juga harus mahir dibanyak bidang. Pengajian yang terus berjalan. Bakti sosial dan membantu menggalang dana untuk bencana. Pelatihan kaderisasi bagi para caleg perempuan dan kader WPP; yang membahas pendidikan politik, politik praktis, menggambarkan situasi dilapangan, bagaimana cara menjaring massa dan memberikan pendidikan politik bagi para pendukungnya. Workshop calon legislative perempuan se Indonesia, yang membahas mengenai; strategi pemenangan Pemilu, politik perempuan, peraihan suara dalam Pemilu dan mengeai parlemen. Banyak sekali kegiatan-kegiatan dan juga pelatihanpelatihan yang diadakan oleh WPP untuk para caleg Perempuan maupun perempuan PPP.

Akan tetapi ketika kita melihat dari sekian banyak kegiatan dan pelatihan yang diadakan sebelum Pemilu 2009, perempuan PPP yang memenangkan Pemilu dan duduk sebagai anggota dewan hanya 5 orang dari 38 orang yang duduk di DPR-RI, dengan persentase $13 \%$. Masih sangat jauh dari angka $30 \%$ yang telah ditetapkan oleh undang-undang, yang juga terdapat di AD/ART PPP maupun WPP sebagai badan otonom perempuan yang terdapat di PPP. Ketika dilihat kembali, dari beberapa wawancara yang penulis lakukan, beberapa program yang berkaitan dengan pendidikan dan bekal politik bagi para perempuan PPP 
dilakukan WPP hanya menjelang Pemilu saja. Dapat diketahui dari kapan saja pelatihan tersebut dilakukan. Dari salah satu wawancara yang penulis lakukan, dikatakan bahwa PPP tidak jarang melakukan rekrutmen pada tingkat nasional melalui cara yang ready to use; Memilih orangorang yang memiliki latar belakang ketokohan, misalnya dari organisasiorganisasi penyedia kader, seperti: HMI (KOHATI), NU (Muslimat NU), Muhammaddiyah (Aisiyah) dan lain sebagainya. Dengan kata lain dalam melakukan rekrutman, PPP lebih menggunakan organisasi-organisasi perempuan yang sudah 'matang' dalam mencari kader. Beberapa tetap mengikuti pelatihan-pelatihan yang diadakan WPP dan ada juga yang tidak. Seperti halnya salah satu caleg yang memenangkan kursi di DPR-RI pada Pemilu 2009 tidak melalui pelatihan-pelatihan yang dilakukan oleh WPP, karena dianggap dapat menjaring suara tanpa melalui pelatihan-pelatihan yang diadakan. Dan hal ini tidak dipermasalahkan karena suara caleg tersebut diyakini dapat memberikan kursi kepada PPP. Dan permasalahan lain yang muncul adalah caleg-caleg yang sudah siap saing ternyata hanya ditempatkan pada 'nomor urut yang tidak jadi'. Sangat sulit sekali ketika bagi caleg perempuan ingin memenangkan kursi ketika mereka tidak ditempatkan pada 'nomor urut jadi'. Hal lainnya adalah tidak jarang caleg-caleg perempuan ditempatkan bukan pada basis massanya.

Pada saat Pemilu salah satu hal yang dapat mendorong para calon legislative perempuan dapat ikut bersaing dalam Pemilu adalah penentuan daftar calon sementara dan daftar calon tetap. Di dalam PPP badan yang menentukan daftar calon tetap sementara dan daftar calon tetap adalah Latjnah Pemenangan Pemilu (LP2), LP2 membantu dan mengurus segala sesuatu yang berhubungan dengan Pemilu tersebut. Badan ini didirikan ketika persiapan Pemilu tersebut dimulai. LP2 terdiri dari kaderkader PPP yang berada di struktur partai. Dan ketika Pemilu 2009 kemarin, di dalam LP2 terdapat beberapa perempuan, akan tetapi WPP sebagai lembaga otonom perempuan PPP tidak memiliki jatah tempat untuk dapat duduk di LP2. Biarpun dibeberapa tempat terdapat anggota-anggota WPP yang terdapat di struktur LP2, akan tetapi bukan merupakan 'jatah' WPP melainkan karena para anggota WPP tersebut juga berada dalam struktur partai. Sehingga WPP yang seharusnya lebih dapat membantu para perempuan-perempuan PPP untuk dapat duduk dilembaga legislative tidak terjadi secara semestinya.

Dalam beberapa kasus terakhir hal yang menyebabkan adalah kader laki-laki yang banyak menduduki jabatan pada tingkat pimpinan, masih meragukan kualitas caleg-caleg perempuan. Permasalahan lain adalah dapat terlihat bahwa permasalahan perempuan khususnya dalam rekrutmen perempuan PPP pada Pemilu 2009 hanya dibahas oleh kalangan-kalangan perempuan saja, padahal apabila ingin menghasilkan perempuan-perempuan yang berkualitas bukan hanya perempuan saja yang harus berkerja keras, akan tetapi laki-laki juga harus ikut serta dalam penyelesaian permasalahn-permasalahn yang ada. Hal-hal sperti ini merupakan akibat dari kultur patriarki yang memang menjadi permasalahan mendasar bagi kaum perempuan.

\section{PENUTUP}

\section{Kesimpulan}

Wanita Persatuan Pembangunan
(WPP) merupakan badan otonom perempuan satu-satunya yang berada di Partai Persatuan Pembangunan. Lahir pada tanggal 12 Agustus 1988 dan seperti Partai 
Persatuan Pembangunan, azas Islam sebagai dasarnya. Wanita Persatuan Pembangunan dibentuk untuk meningkatkan kualitas perempuan secara umum dan meningatkan partisipasi kader perempuan PPP didunia politik secara khususnya. Banyak programprogram yang diadakan oleh Wanita Persatuan Pembangunan untuk mempersiapkan perempuan-perempuan yang berkualitas, seperta: pelatihan Trainning of Trainers (TOT); Pelatihan kewirausahaan; Pengajian; Bakti sosial dan membantu menggalang dana untuk bencana; Pelatihan kaderisasi; Workshop calon legislative perempuan se Indonesia. Hal ini juga diadakan Wanita Persatuan Pembangunan pada rekrutmen perempuan PPP pada Pemilu 2009.

Pemilu tahun 2009 keterwakilan perempuan yang akhirnya dapat duduk di DPR hanya $13 \%$, yaitu 5 perempuan dari 38 orang laki-laki dari Partai Persatuan Pembangunan yang duduk di DPR-RI. Beberapa penyebabnya adalah program yang berkaitan dengan pendidikan dan bekal politik bagi para perempuan PPP dilakukan WPP hanya menjelang Pemilu saja, mengambil kader-kader yang ready to use agar dapat memenangkan suara tanpa melalui pelatihan-pelatihan yang ada. Dan budaya patriarki yang masih sangat kental dirasakan bahwa kader-kader yang dianggap lebih berkualiatas; yang sebagian besar lakilaki yang ditempatkan pada nomor urut jadi dan dapil yang sesuai.

DAFTAR PUSTAKA

Arivia, Gadis. 2005. Sekapur Sirih dalam Politik Perempuan Bukan Gerhana. Jakarta : Penerbit Kompas.

Dahlerup, Drude. 2002. Menggunakan Kuota untuk Meningkatkan Representasi Politik Perempuan dalam Perempuan di Parlemen: Bukan Sekedar Jumlah, IDEA, 2002.
Lexy J. Moleong, 2002. Metodologi Penelitian Kualitatif, Bandung : Remaja Rosda Karya.

Fakih, Mansour. Mansour, 2008. Analisis Gender \& Transformasi Sosial, Yogyakarta: Insist Press.

Gaffar, Afan. 1999. "Demokrasi Empiris dalam Era Orde Baru" dalam Alfian dan Nazarudin Sjamsuddin (eds.). Budaya Politik Indonesia. Jakarta, Grafitti.

Haryanto,1984. Sistem Politik: Suatu Pengantar, Liberty, Yogyakarta.

Imawan, Riswandha Imawan. Proses Pencalonan dan Calon dalam Pemilu 1992. Makalah disampaikan dalam Seminar Nasional IX, Asosiasi Ilmu Politik Indonesia, Surabaya, Agustus 1992.

Kymlicka, Will, 2002. Kewargaan Multikultural, Penterjemah; Edlina Hafmini Eddin, Pustaka LP3ES, Jakarta.

Napsiah, 2009. Nilai-nilai Profetik dan Affirmative Action di Partai Politik dalam Gender dan Politik. Yogyakarta : Tiara Wacana.

Rush Michael, Phillip Althoff, 2003. Pengantar Sosiologi Politik. Jakarta, PT Raja Grafindo Persada.

Sastriyani, Siti H. 2009. Gender and Politics, Yogyakarta:Tiara Wacana, 2009.

Subono, Nur Iman. 2003. Perempuan dan Partisipasi Politik: Panduan untuk Jurnalis. Jakarta: Yayasan Jurnal Perempuan dan The Japan Foundation.

Sulastri, Endangi. Pola Rekrutmen Caleg Perempuan Pada Partai Persatuan Pembangunan Pada Pemilu 1999.Thesis. Universitas Indonesia.

Ware, Alan. 2000. Political Parties and Party System, Oxford University Press, New York. 
Kantor Mentri Negara Pemberdayaan Perempuan Republik Indonesia dan Women Support Project II/CIDA, Gender dan Pembangunan, 2001, Hal. 15

Media Indonesia, tanggal 29 Desember 2009. 